\title{
Application Considerations for Successful Use of VIF and Metalized Mulches with Reduced Fumigant Rates in Tomato ${ }^{1}$
}

Jim Gilreath, Bielinski Santos, John Mirusso, Joe Noling and Phyllis Gilreath ${ }^{2}$

Methyl bromide (MBr) alone, or in combination with chloropicrin (Pic), has been the soil fumigant of choice since the early 1970s (Overman and Martin, 1978), because of its ease of use and high efficacy under a wide range of conditions. It is typically shank-injected at $350 \mathrm{lb} / \mathrm{acre}$ to a soil depth of 10 inches into raised beds that are simultaneously covered with LDPE mulch. Standard LDPE is inexpensive and easy to use, but it is highly permeable to $\mathrm{MBr}$ (Gamliel et al., 1998a, 1998b; Papiernik and Yates, 2001; Williams et al., 1999; Yates et al., 1996a, 1996b). MBr has been classified as a substance that contributes to depletion of stratospheric ozone. Consequently, a complete phase-out of the use and production of $\mathrm{MBr}$ in developed countries throughout the world was scheduled to occur by 2005 , with critical use exemptions permitted under the Montreal Protocol (U.S. Environmental Protection Agency, 1999). Critical use exemptions (CUE) are important for minor crops because growers feel that an economically and technically viable $\mathrm{MBr}$ alternative is not yet commercially available. However, even with permitted exemptions, reduced rates of $\mathrm{MBr}$ may be needed to offset the rising cost of the fumigant and to reduce atmospheric emissions. Reduced emissions probably will be a requirement for future CUEs.

To obtain a high degree of pest control with a fumigant, it is necessary to maintain a sufficient quantity of fumigant gas in the soil long enough to reduce the population of pests (Gamliel et al., 1998b; Minuto et al., 1999). This might be accomplished by using low rates of $\mathrm{MBr}$ under highly retentive or reduced permeability film. Virtually impermeable film (VIF) is so named due to the much higher fumigant retention capacity of this film compared to ldpe and hdpe which have been the historical mainstays of plasticulture. VIF has become commercially available in recent years and is much more retentive of fumigant gases than standard ldpe mulch (Papiernik and Yates, 2001). This type of film increases fumigant toxicity by increasing the duration of retention, which is caused by a barrier polymer, such as ethylene vinyl alcohol or nylon, placed between two layers of polyethylene (Papiernik and

1. This document is HS287, a publication of the Horticultural Sciences Department, Florida Cooperative Extension Service, IFAS, University of Florida. Published August 2005. Visit the EDIS Website at http://gcrec.ifas.ufl.edu.

2. Jim Gilreath, professor, Gulf Coast Research and Education Center; Bielinski Santos, research associate, Gulf Coast Research and Education Center; John Mirusso, Mirusso Enterprises, Inc., Delray Beach; Joe Noling, professor, Citrus Research and Education Center; Phyllis Gilreath, extension agent, Florida Cooperative Extension Service, Manatee County, University of Florida, Gainesville, FL 32611.

The Institute of Food and Agricultural Sciences (IFAS) is an Equal Opportunity Institution authorized to provide research, educational information and other services only to individuals and institutions that function with non-discrimination with respect to race, creed, color, religion, age, disability, sex, sexual orientation, marital status, national origin, political opinions or affiliations. U.S. Department of Agriculture, Cooperative Extension Service, University of Florida, IFAS, Florida A. \& M. University Cooperative Extension Program, and Boards of County Commissioners Cooperating. Larry Arrington, Dean 
Yates, 2001). Wang et al. (1997) determined that atmospheric emission of $\mathrm{MBr}$, when covered with polyethylene for 5 days, declined from $64 \%$ of applied $\mathrm{MBr}$ with conventional LDPE mulch to about $38 \%$ with VIF. With the soil covered by VIF for more than 10 days, only $1 \%$ to $3 \%$ of the $\mathrm{MBr}$ was lost.

In the past six years, considerable field research and grower trials have been conducted with these VIF mulches in Florida. Small plot studies demonstrated that nutsedge and stunt nematodes could be controlled and crop yields maintained with rates of $\mathrm{MBr} / \mathrm{Pic}$ (67/33 formulation) as low as one-fourth $(88 \mathrm{lb} . /$ treated acre) of the standard use rate of $350 \mathrm{lb}$./treated acre when combined with some VIF mulch films, while grower trials successfully established the commercial potential of one-half normal rates (Gilreath et al., 2005a; Santos et al., 2005). Additional research indicated that this improvement in fumigant retention and control of soilborne pests with VIF was not restricted to just $\mathrm{MBr}$, but also included 1,3-D-based fumigants like Telone C-35 and Inline (Gilreath et al, 2004; Hochmuth et al, 2003). Preliminary data indicate similar results with other fumigants such as methyl iodide (Midas).

Unfortunately, there are two drawbacks to most VIF products: cost and handling characteristics. Today, all VIF is made in Europe and must be imported, thus resulting in much higher cost than standard film. Also, most of the VIF products are more difficult to lay than standard films in that they are prone to linear sheer if subjected to too much tension during laying. There is considerable difference in handling characteristics among VIF materials, but they are all based on polyamides, such as nylon, for their barrier properties and these polyamides do not stretch well. Also, none are embossed at the present time. High barrier films continue to be evaluated as they become available, but to date Bromostop ${ }^{\circledR}$ VIF has been the most consistent performer and appears to handle the best under our conditions.

Recognizing the problems associated with some of the existing VIF, we continue to search for other mulch films with enhanced barrier properties. Over the past 2 years, we have examined the barrier properties of metalized films under field conditions, first with 1,3-D (Inline) and more recently with MBr. In each case, application of Inline or $\mathrm{MBr}$ in conjunction with metalized film greatly increased the retention of the fumigant (Gilreath et al., 2005b). In the case of $\mathrm{MBr}$, we were able to obtain nutsedge control with $175 \mathrm{lb}$./acre of 67/33 under Canslit ${ }^{\circledR}$ metalized film that was equal or superior to that obtained with the full $350 \mathrm{lb}$./acre rate under standard ldpe or hdpe film in each of four experiments. Bromostop ${ }^{\circledR}$ VIF was included in each of these experiments and the field performance for gas retention under the mulch film, as well as nutsedge control and fruit production, was similar between Canslit ${ }^{\circledR}$ metalized film and VIF. Grower trials with Canslit ${ }^{\circledR}$ metalized film confirmed these results. Additionally, we determined that the retention of $\mathrm{MBr}$ and resultant nutsedge control with Canslit ${ }^{\circledR}$ metalized film was similar to what we obtained with VIF at every rate of $\mathrm{MBr}$, ranging from 88 to 350 lb./acre of 67/33.

While it is possible to use Bromostop ${ }^{\circledR}$ VIF or Canslit $\AA$ metalized film to reduce $\mathrm{MBr}$ usage rates by one-half, successful use involves more than just reducing gas flow and laying mulch film. $\mathrm{MBr}$ has a high vapor pressure, which means that at typical application temperatures it rapidly becomes a gas and can do so even within the tubing and gas knives of the application rig. This is an advantage for reduced rate application, but it does not solve one inherent problem - uniformity of application. Typical gas rigs employ 3 knives per bed. A good fumigation job requires that all 3 knives deliver the same amount of product per minute so that the application rate is uniform in the area being fumigated. When the rate is reduced, there is less fumigant in the system and more opportunity for the formation of bubbles as the $\mathrm{MBr}$ "boils". Inserting small sight glasses in the application equipment at the flow divider just ahead of the tubes which carry the fumigant to the knives will allow you to observe this "boiling" (Figure 1). Under normal conditions, a certain amount of back pressure exists in the application system and can be measured at the flow divider by installing a pressure gauge. Application of a full $350 \mathrm{lb}$./acre rate will generate in excess of $30 \mathrm{psi}$ of back pressure at this point. Reducing the methyl bromide flow rate in order to deliver lower rates per acre will reduce the 
back pressure measured at the flow divider. Our experience indicates that back pressure below 15 psi results in nonuniform distribution to the three knives which means inequalities in rate across the bed. Usually the edges suffer the most and this effect can be observed later in the season as poor control of nutsedge on bed shoulders.

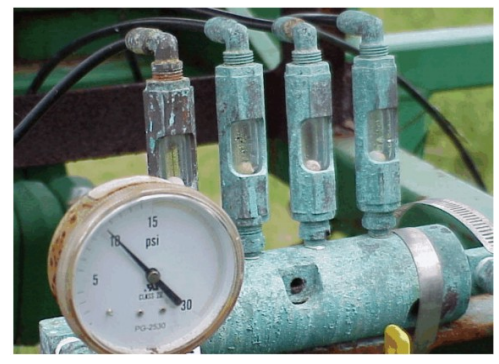

In order to increase back pressure when using low rates of $\mathrm{MBr}$ or any other fumigant, you must decrease the flow capacity of the delivery system between the flow divider and the gas knives. This can be accomplished in two ways. First, you can use a smaller diameter tubing to deliver fumigant to the gas knives. Standard gas rigs use tubing which is one-quarter inch inside diameter. While this is fine for a gas with high vapor pressure like $\mathrm{MBr}$ or for high flow rates of other fumigants, it may not be suitable in other situations. We have found that the use of poly tubing ranging from one-sixteenth to one-eighth inch inside diameter is necessary in order to achieve balanced or uniform delivery of greatly reduced rates of $\mathrm{MBr}$. Tubing of this size is not readily available, but it can be obtained and is an important modification if a grower is going to use reduced rates of $\mathrm{MBr}$ with a highly retentive film like Canslit ${ }^{\circledR}$ metalized or Bromostop ${ }^{\circledR}$ VIF. Fine tuning of flow capacity or rate of any tube can be accomplished by increasing or decreasing the length of the tube connecting the flow divider to the gas knife. There is a certain amount of friction loss of flow within any size tube and the effect of friction increases with increased length and decreased tubing inside diameter. Typical length for one-sixteenth and one-eighth inch tubing is $5 \mathrm{ft}$; although longer tubing has been used when trying to achieve really low rates. Color coded tubing is available which can be a big help when adjusting flow rates. Yellow tubing has the thickest walls and smallest inside diameter of one-sixteenth inch. Black tubing is available in one-eighth inch inside diameter (Figure 2). These tubes all fit the same size connector, making it easy to switch from one flow capacity to another. Select the tube needed for the desired flow capacity, then once installed, adjust the flow regulator valve for the required flow rate on the flow meter, just like normal.

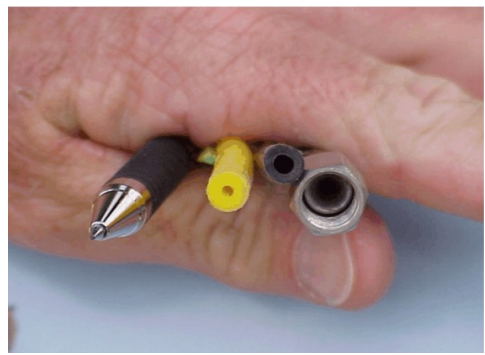

A second way to decrease flow and increase back pressure is to use orifice plates (Teejet ${ }^{\circledR}$ flow regulators) in the tubing at the top of the gas knife fitting. In order to use these plates, you have to know what flow rate you need in each tube. Since the flow rates of orifice plates are based on water, you have to do some mathematical conversions to $\mathrm{MBr}$ or choose one on the high side and try it. In any event, you do not want a plate which gives you the exact same flow rate as what you need; you want one with a slightly higher flow rate so that clogging potential is lowered. If you are going to use orifice plates, you should keep a supply of various sizes on hand. The plates have numbers stamped on them which tell you the size of the hole in the plate (Figure 3). Be sure to keep your glasses handy because these can be hard to read. Orifice plates work over a more narrow range of rates than tubing because the restriction in flow occurs at one point rather than over a length of tubing.

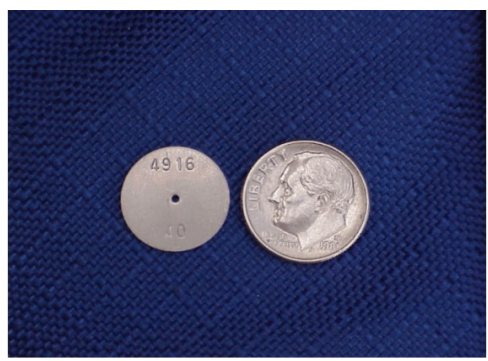

The system we use is commercially available (manufactured by Mirusso Enterprises, Inc., available through Chemical Containers, Inc.) and constitutes an easily installed, simple modification. It consists of a flow divider with a small sight glass for each knife, a 0 to 30 psi pressure gauge and small diameter poly tubing. The sight glasses are equipped with standard quick connect (insert friction connectors) couplings 
on top so the poly tube easily can be connected and disconnected. Similar couplings are located on the top of the gas knives. Sight glasses are useful because they allow you to monitor flow and detect plugging of chisels or lines. Plugging can be a significant issue with low rates of fumigant. As a result, fumigant filtration is even more important and filters need to be checked periodically and maintained clean and free of trash to assure consistent flow through the fumigant distribution system.

One thing to remember when using reduced rates of fumigant: the flow rate has been greatly diminished so accuracy and uniformity of delivery are critical. A common observation on commercial farms is tractor movement as soon as the fumigant flow valve is opened. There is a much longer delay in supplying all the knives uniformly when the rate is reduced, so tractor movement should not begin until all lines are fully charged. You can monitor this condition easily by observing the sight gauges and back pressure gauge. Once the back pressure stabilizes, you can begin fumigation. Addition of an inline check valve at the top of each gas knife can be beneficial because it diminishes loss of fumigant out of the line to the knife. Keep the line full all the way to the gas knife to minimize delays in fumigant delivery and to avoid wasting time purging air from lines. This would be especially important for those growers who use radar-controlled fumigant delivery systems.

Rate reduction with $\mathrm{MBr}$ works when combined with a highly retentive mulch film like VIF or metalized film. In addtion to the use of the right film, success requires close monitoring of fumigant delivery, assuring not only that the rate is correct, but also that it is applied uniformly to all three knives in the bed. Nonuniformity guarantees poor fumigant performance at any rate, but with reduced rates of $\mathrm{MBr}$, the results can be even more dramatic. The simple modifications described above can greatly improve uniformity of delivery and performance. These modifications are relatively inexpensive and are readily available as a package. Before trying rate reductions growers should modify their fumigation equipment to allow better control over uniformity of flow. This can mean the difference between success and failure. Under no conditions should a grower attempt to reduce his methyl bromide rate by more than $50 \%$ of the standard use rate the first time around. Rates lower than $50 \%$ are possible, but it is difficult to achieve the required level of application uniformity and accuracy without considerable experience and attention to detail. Growers should gain experience with rate reduction and use of barrier films because this will be the future and the future is now.

\section{Important Facts To Consider}

- Not all VIF or metalized films are the same.

- Gas retention with VIF mulch is fairly consistent among manufacturers, but handling properties may differ greatly.

- Gas retention among metalized films may vary by manufacturer. Not all have been tested at this time.

- One manifestation of non-uniformity of delivery of fumigant may be nutsedge on the bed shoulders but not in the middle of the bed.

- Rate reduction requires close attention to uniformity of application.

- Uniformity requires balanced flow between all chisels or knives.

- Balanced flow requires sufficient back pressure on gas lines (at least $15 \mathrm{psi}$ at the flow divider).

- Back pressure can be achieved by impeding flow at the chisels.

- Reduced flow rate at the chisel can be obtained by reduction of line size (1/8th to 1/16th inch inside diameter) from the flow divider to the chisel or by using Teejet ${ }^{\circledR}$ flow regulators (orifice plates).

- Back pressure can be adjusted by selecting the length and inside diameter of small diameter tubing from the flow divider to the chisel or by selecting the proper size orifice plate based on mathematical calculations. 
- Methyl bromide rates of $1 / 2$ the normal 350 $\mathrm{lb}$./treated acre rate generally require at least $5 \mathrm{ft}$ of $1 / 8$ th inch inside diameter tubing from the flow divider to each chisel.

- Methyl bromide rates below $175 \mathrm{lb}$./treated acre may require 5 or more feet of $1 / 16$ inch inside diameter tubing.

\section{References}

Gamliel, A., A. Grinstein, M. Beniches, J. Katan, J. Fritsch, and P. Ducom. 1998a. Permeability of plastic films to methyl bromide: A comparative laboratory study. Pesticide Sci. 53:141-148.

Gamliel, A., A. Grinstein, L. Klein, Y. Cohen, and J. Katan. 1998b. Permeability of plastic films to methyl bromide: Field study. Crop Protection $17: 241-248$.

Gilreath, J.P., T.N. Motis, and B.M. Santos. 2005a. Cyperus spp. control with reduced methyl bromide plus chloropicrin rates under virtually impermeable films in pepper. Crop Protection 24:285-287.

Gilreath, J. P., M. N. Siham and B. M. Santos. 2005b. Nutsedge (Cyperus spp.) control and methyl bromide retention with different mulches. Proc. Fla. State Hort. Soc. 2005 (in press).

Minuto, A., A. Gilardi, M.L. Gullino, and A. Garibaldi. 1999. Reduced dosages of methyl bromide applied under gas impermeable plastic films for controlling soilborne pathogens of vegetable crops. Crop Protection 18:365-371.

Overman, A.J. and F.G. Martin. 1978. A survey of soil and crop management practices in the Florida tomato industry. Proc. Fla. State Hort. Soc.

91:294-297.

Papiernik, S.K. and S.R. Yates. 2001. Transport of fumigant compounds through HDPE and virtually impermeable films. Proc. Annu. Intl. Res. Conf. Methyl Bromide Alternatives and Emissions Reductions 10:16 (Abstr.).

Santos, B. M., J. P. Gilreath and T. N. Motis. 2005. Managing nutsedge and stunt nematode in pepper with reduced methyl bromide plus chloropicrin rates under Virtually Impermeable Films. HortTechnology 15:6-9.

U.S. Environmental Protection Agency. 1999. Protection of stratospheric ozone: Incorporation of Montreal protocol adjustment for a 1999 interim reduction in Class I, Group VI controlled substances. Federal Register 64:29240-29245.

Wang, D., S.R. Yates, F.F. Ernst, J. Gan, and W.A. Jury, W.A. 1997. Reducing methyl bromide emission with a high barrier plastic film and reduced dosage. Environ. Sci. Technol. 31:3686-3691.

Williams J., N.Y. Wang, and R.J. Cicerone. 1999. Methyl bromide emissions from agricultural field fumigations in California. J. Geophysical Res.-Atmospheres 104:30087-30096.

Yates, S.R., F.F. Ernst, J. Gan, F. Gao, and M.V. Yates. 1996a. Methyl bromide emissions from a covered field. 2. Volatilization. J. Environ. Quality 25:192-202.

Yates, S.R., J. Gan, F.F. Ernst, A. Mutziger, and M.V. Yates. 1996b. Methyl bromide emissions from a covered field. 1. Experimental conditions and degradation in soil. J. Environ. Quality 25:184-192. 